\title{
Propagating the fear of witchcraft: Pentecostal prophecies in the new prophetic churches in South Africa
}

\section{Mookgo Solomon Kgatle}

Department of Christian Spirituality, Church History and Missiology, College of Human Sciences, University of South Africa (UNISA) Pretoria, South Africa

\begin{abstract}
Pentecostal prophecy is one of the major themes of the theology and practice of religion among the prophets of New Prophetic Churches in South Africa and a major factor to the growth and expansion of Pentecostalism in Southern Africa. This paper offers a reflection on the role of prophecy in relation to the fear of witchcraft in the region. The contribution is that Pentecostal prophecy is not always in confrontation but sometime propels the fear of witchcraft. Through media analysis, the paper illustrates with some examples of Pentecostal prophecies on witchcraft how Pentecostal prophecy can aid rather than dispel fear of witchcraft. These prophecies raise several challenges to the discernment of Pentecostal prophetic ministry.
\end{abstract}

\section{KEYWORDS}

Prophecy; Pentecostalism; witchcraft; new prophetic churches; fear; South Africa

\section{Introduction}

Many Pentecostal scholars have reflected on the fear of witchcraft in African Pentecostalism from western African countries like Ghana and southern African countries like Botswana and Zimbabwe. Similarly, much has been written on how Pentecostals in various regions in Africa confront the problem of the fear of witchcraft. Several studies in West Africa illustrate how deliverance $^{1}$ in Pentecostalism is used to confront the powers of witchcraft. ${ }^{2}$ In a Southern African context, works by emerging scholars have recently pointed to the confrontation of witchcraft by several Pentecostal groups. ${ }^{3}$ Yet, one may argue that Pentecostalism is not always in confrontation with the fear of witchcraft but at times propels the same fear. This essay pays attention to the

\footnotetext{
${ }^{1}$ Deliverance is another form of exorcism where the deliverer used various methods to drive out the demons inside their followers. There are two types of deliverance methods in Pentecostalism, public and private. Depending on the type of problem, the believer might be asked to fast for some days in order to make deliverance possible. In a public deliverance session, the deliverer or pastor will deliver a sermon, ask for testimonies and later call for those who need deliverance to come to the podium.

${ }^{2} \mathrm{Cf}$. Onyinah, "Deliverance as a Way of Confronting Witchcraft in Modern Africa"; Quayesi-Amakye, "This Nonsense Must Stop"; Asamoah-Gyadu, "Witchcraft Accusations and Christianity in Africa."

${ }^{3}$ Baloyi, "A Pastoral Examination"; Banda and Masengwe, "Overcoming fear"; Banda, "A Soteriological Response" all point to strategies for Pentecostals in Southern Africa to deal with the fear of witchcraft although they do not address the problem of the propagation of the fear of witchcraft within Pentecostalism.
} 
fear of witchcraft within the so-called New Prophetic Churches (NPCs) in South Africa by using Pentecostal prophecy as a theoretical framework and media content analysis as a method of data collection to illustrate the propagation of the fear of witchcraft by NPCs. The resulting analysis highlights specific challenges with these types of prophecies including the defamation of character of individuals, division of families, financial, and psychological problems. In dealing with these challenges of Pentecostal prophecies on witchcraft, I suggest that prophecy should serve as edification, unification, and affirmation of scripture while believers should be instructed to distinguish between true and false prophecy.

This paper will use media content analysis based on articles from the main newspapers in South Africa as well as audio-visual material from other platforms including social media. The various material on the NPCs prophets is analysed by focusing on the articulation and function of witchcraft prophecies, particularly on the content of the prophecies that relate to the fear of witchcraft. ${ }^{4}$ The analysis pays attention to the content of the media coverage and the effects on the followers of NPCs and other audiences who had access to the material in order to identify instances where the prophecies either confronted the fear of witchcraft or propagated it. I suggest that this analysis will assist not only in identifying the problematic nature of the prophecies but also in paving a way to address the challenges of propelling the fear of witchcraft among Pentecostals.

\section{Characterization of NPCs in South Africa}

The study of NPCs in South Africa should be placed in the wider context of the study of South African Pentecostalism, which includes churches that can be classified as Pentecostal Charismatic Churches (PPC), the African Independent Churches (AICs), and Independent Charismatic Churches (ICC). ${ }^{5}$ However, since the beginning of South African democracy, there is a resurgence of a new type of churches that cannot be classified within the above three categories. These new churches I have called 'fourth wave' are characterized by new-prophetism that includes prophetic titles, prophetic consultations, prophetic objects and prophetic miracles. ${ }^{6}$ The fourth wave of Pentecostals includes churches like the Enlightened Christian Gathering (ECG) of Prophet Shepherd Bushiri in Pretoria, Alleluia ministries of Pastor Alph Lukau in Sandton, Rabonni Ministries of Pastor Daniel Lesego in Soshanguve and Incredible

\footnotetext{
${ }^{4} \mathrm{Cf}$. Macnamara, "Media content analysis," 4.

${ }^{5}$ Anderson, "New African Initiated Pentecostalism" is one of the few Pentecostal scholars that classify AICs within the broad Pentecostal movement. For other references on South African Pentecostalism, see Derrick Mashau, "Ministering Effectively," 10-17.

${ }^{6} \mathrm{Kgatle}$, The Fourth Pentecostal Wave in South Africa.
} 
Happenings of Pastor Paseka Motsoeneng. ${ }^{7}$ These churches and their leaders can be categorized within Pentecostalism because many of them have retained the fundamental teachings of Pentecostalism. It is therefore necessary to explain the nature of Pentecostal prophecy before we can understand its relation to the fear of witchcraft.

\section{A definition of Pentecostal prophecy in NPCs}

Pentecostal prophecy as practiced by NPCs prophets is not much different from divination as practiced by African Traditional Religions (ATR) where the diviner is able to predict the problem faced by the recipient of the prophecy. ${ }^{8}$ Similar to divination in ATR, the prophet is able to reveal the personal details of the person receiving the prophecy. These are details like the residential addresses, contact details like cell numbers, marital statuses, and diets. The NPCs prophets are also able to reveal where and with whom people slept. ${ }^{9}$ What is very much peculiar about this type of prophecy is that, unlike in ATR, it is done in public in front of cameras within NPCs. Thus, the congregants stand a risk of being exposed especially if the prophecy involves their private lives. However, those who wish to receive the prophecy in the privacy with the prophet can do so by paying a certain consultation fee. ${ }^{10}$ The concept of privately visiting a prophet to enquire from him or her is called 'one-on-one prophecy' and many followers continue to pay large amounts of money in order to consult their 'men or women of God'11 $^{11}$ in private.

\section{Pentecostal prophecies on witchcraft among NPCs}

The controversial and well-known Prophet Shepherd Bushiri of ECG is said to have conducted the first witchcraft prophecy. In the prophecy, Bushiri made claims to one of his employees, Sibongile Mable Miya (later Miya) that the wife of her ex-husband, Lebohang Mpane (later Mpane), bewitches her. ${ }^{12}$ In these claims, delivered during the service at ECG, which was broadcasted live on Prophetic channel ${ }^{13}$ and later posted on YouTube, ${ }^{14}$ Bushiri called Mpane a sangoma, a term that refers to a traditional healer but is sometimes used in a defamatory sense to identify a 'witchdoctor'. The claims made in the name of prophecy made clear that Mpane had stolen her husband from Miya by using witchcraft to influence him and the children. The so-called prophecy

\footnotetext{
${ }^{7}$ Cf. Dube, "Go and Prophesy in Your Own Land," 42; Ramantswana, "Prophets Praying for, or Preying on People's Faith," 8.

${ }^{8}$ Chimuka, "Afro-Pentecostalism" draws some parallelism between Pentecostal prophecies as practiced by NPCs prophets with the prophecy as practiced by diviners within ATR.

${ }^{9}$ See Kgatle, "Reimagining the Practice of Pentecostal Prophecy," 8.

${ }^{10}$ lbid., 4.

${ }^{11}$ See Tsekpoe, "Contemporary Prophetic and Deliverance Ministry Challenges in Africa," 280-91.

${ }^{12}$ Mothombeni, "Bushiri Sued Millions over Witchcraft Prophecy."

${ }^{13}$ Prophetic channel is an official television station owned by ECG and broadcasts every service live.

${ }^{14}$ Prophet Shepherd Bushiri, "The Prophetic Gymnastics: Exposing Witchcraft Spirit."
} 
was also very particular in indicating that Miya converted the husband to be a sangoma as well. ${ }^{15}$ Consequently, these claims affected the business of Mpane as the perception of people changed since many of her colleagues and business associates knew about the claims. Equally, the claims in the name of prophecy affected the marriage of Mpane as her husband resigned from his work because of the allegations of witchcraft and suffered a lot of stress and trauma since she knew about the claims. ${ }^{16}$

A second example is Pastor Paseka Motsoeneng, who begun a journey and operation that he called 'Tswara Moloi' which is Northern Sotho for 'Catch a witch'. ${ }^{17}$ In this operation, Motsoeneng has argued to his congregants that witchcraft exist in South Africa and that it is the main cause for many challenges that people experience. ${ }^{18}$

People, particularly black people, are suffering. Whether you believe it or not, witches and wizards are real and people are suffering because of them. I am going to end their reign of terror and will free their victims through prayer and the name of Jesus. We are going to show people that the power of God exists and is able to diminish all other powers like that of witches. ${ }^{19}$

Although, Motsoeneng, unlike Bushiri, promised not to expose people publicly, as he might be in trouble with the law, the challenge is that he is still willing to allow confessions in the pulpit. ${ }^{20}$ Therefore, whether through prophecy or confession, there are repercussions for exposing witchcraft publicly in the church and particularly when services are broadcast on television. In addition, by requesting those who are bewitched to bring the soil of their homes to the church, Motsoeneng is can be seen as presenting another form of witchcraft. ${ }^{21}$

A final example of witchcraft prophecy was delivered by Pastor Alph Lukau about a woman who was supposed to be initiated as a sangoma, a practice which from a distance seemed to be in confrontation with the practices of witchcraft and ancestral spirits. ${ }^{22}$ However, a closer look at this prophecy reveals the opposite. In the prophecy, Lukau reveals that the woman who was supposed to be initiated as a witchdoctor could not do so because she was charged five cows, a price which was out of her reach. Although the prophecy indicates that her official initiation to become a sangoma has failed due to her failure to raise the money, people who are closer to her continue to remember her as a sangoma. ${ }^{23}$ Furthermore, in the prophecy the pastor reveals that the colleagues of the woman have actually set her up so that she lost her job. ${ }^{24}$ This brought

\footnotetext{
${ }^{15}$ Mothombeni, "Bushiri Sued Millions over Witchcraft Prophecy," 1.

${ }^{16} \mathrm{Ibid}$.

${ }^{17}$ Kekana, "Tswara Moloi-Pastor Mboro is on a Mission to Stop Witchcraft."

${ }^{18} \mathrm{lbid}$.

${ }^{19}$ Ibid.

${ }^{20} \mathrm{lbid}$.

${ }^{21}$ Ibid.

${ }^{22}$ Pastor Alph Lukau, "5 Cows for Witchcraft Initiation - Accurate Prophecy with Alph Lukau."

${ }^{23}$ Ibid.

${ }^{24}$ Ibid.
} 
acrimony between people who worked together on a daily basis and can be a root for hatred in workplace. The woman was finally told that she did not have to pay five cows in order to get help. ${ }^{25}$ However, the negativity around her as someone who is about to become a witchdoctor had already caused significant damage in the church and online.

\section{Challenges with Pentecostal prophecies on witchcraft}

The prophecies on witchcraft as delivered by some prophets in NPCs raise challenges especially because they were broadcasted live on television and later posted on YouTube. The immediate challenge is a defamation of character of the person accused of witchcraft in the name of prophecy. As highlighted above, the prophecies were delivered in the public domain by naming and shaming the witch by allowing that all the people who were present in the church and those who watched the video had an opportunity to identify the witch. Since this practice resulted in clear defamation of character, Bushiri is facing criminal charges as his prophecy compromised the human dignity of the victim. $^{26}$ Pentecostal prophecies on witchcraft have potential to ruin the character of the person who is the object of the prophecy and in turn of the person delivering the prophecy. The public cases have caused harm beyond the immediate participants to the churches and congregations which are impacted not only because the prophets are absent from the pulpit running in and out of courts but also because the public scandal places the churches as a whole in a negative light.

A second challenge is that the Pentecostal prophecies not only involve the individual who is the object of the prophetic word but affect other family members as well. In the words of Sanou, the effects of witchcraft do not end with the individual but also have the potential to affect their families, the churches, and the community at large. ${ }^{27}$ Quayesi-Amakye points out that whenever witchcraft is exposed in public those who are close to the person accused will equally be seen as devils. ${ }^{28}$ In addition, witchcraft accusations have the potential to cause fights among family members, destroy relationships and cause other confusions among the people including tribal conflicts. ${ }^{29}$ Sometimes, a specific family may decide to isolate a family member from their household because of being accused of witchcraft. ${ }^{30}$ Hence, according to Tweneboah, 'those victimized as witches and their frustrated families have often sought for an "off legal" settlement or silence over the issue in order to save the image of

\footnotetext{
${ }^{25} \mathrm{Ibid}$.

${ }^{26}$ Mothombeni, "Bushiri Sued Millions over Witchcraft Prophecy," 1. Cf. Sangala, "Shepherd Bushiri Hands Himself to South Africa Police."

${ }^{27}$ Sanou, "Witchcraft Accusations," 33-44.

${ }^{28}$ Quayesi-Amakye, "This Nonsense Must Stop."

${ }^{29}$ Baloyi, "A Pastoral Examination," 2.

${ }^{30}$ Tweneboah, "Pentecostalism, Witchdemonic Accusations," 375-93.
} 
the family' ${ }^{31}$ However, since families cannot do much to protect the identity of the victim as many prophecies are broadcasted live on television, any measure that the family takes will be too late, as the news would have spread within hours after the broadcast of the prophecy.

A third challenge is the financial implications of the prophecy as it is seen in the case of Mpane's husband, who had to resign from his workplace. Consequently, the prophecy affected his finances and ability to support his family. Mpane's businesses were affected as many of her associates abandoned her because of the accusations. ${ }^{32}$ The prophecy on witchcraft holds potential to bring financial distress upon the whole family to an extent that threatens their livelihood. The prophecies disassociate people from those next to them, their families, friends, and associates, so that both the individuals accused of witchcraft and their families end up suffering.

A final challenge is the psychological agony of the victim who suffer stress and trauma because of their exposed in front of other congregants and on television. Mpane, for example, said that she 'suffered a great deal of stress and trauma as a result and she was now taking medication to deal with her condition'. ${ }^{33}$ This challenge is a culmination of the other trials, and Adinkrah concludes, 'For many suspected or accused witches, defamation of their character and loss of their reputation is a major source of emotional trauma and mental distress' ${ }^{34}$ Tedam adds: "To be accused of being a "witch" therefore is unfortunate and can and does result in exclusion, expulsion, torture and abuse of physical, psychological and emotional nature. ${ }^{35}$ The ultimate challenge is not necessarily the immediate accusation or the prophecy itself but that victims cannot cope with the fact that other people know about the accusation. It is worse when such accusation affects their family members to an extent of touching their livelihood in a way that they can no longer cope.

\section{Pentecostal prophecies on witchcraft: confrontation or propagation?}

Pentecostal scholars have critically discussed the role of Pentecostalism in confronting and overcoming the fear of witchcraft. Opoku Onyinah, a Ghanaian Pentecostal scholar uses the terms 'witchdemonology' and 'deliverance' that are common in Ghana when praying for believers to receive freedom from witchcraft, generational curses, diseases, lack of jobs, poverty and so forth. ${ }^{36}$ The reason for the emphasis on deliverance by many Pentecostal pastors is simple: they see the devil as the main source of all the problems happening to believers. There is therefore an association between societal problems and

\footnotetext{
${ }^{31}$ lbid., 392.

${ }^{32}$ Mothombeni, "Bushiri Sued Millions over Witchcraft Prophecy," 1.

${ }^{33}$ lbid., 1.

${ }^{34}$ Adinkrah, "Child Witch Hunts," 741-52.

${ }^{35}$ Tedam, "Witchcraft branding," 1403-14.

${ }^{36}$ Onyinah, "Deliverance as a Way of Confronting Witchcraft," 122.
} 
demon possession in the spirit world, which is followed, by an association with witchcraft. ${ }^{37}$ Similarly, as pointed out by Asamoah-Gyadu 'in the Christian mindset, witches have survived as demons, which means witchcraft activity is synonymous with demonic activity, and therefore the source of witchcraft is seen as being demonized by the devil, or Satan'. ${ }^{38}$ Thus, in many Pentecostal churches in Africa, it is not enough for a Christian to be born again; they also need deliverance because of the demonic influences on their lives. ${ }^{39}$ Hence, the message of deliverance from witches and the power of Satan has been one of the reason for the growth and expansion of Pentecostalism. ${ }^{40}$

The NPC prophets are in agreement with their forbearers in linking the problems encountered by believers with the spirit world; however, they differ in addressing the problems. The NPCs are not experts in deliverance ministries but are centred on prophecy, a ministry marked by prophetic titles, consultations, miracles, and objects. Therefore, in taking advantage of the fear of witchcraft among their followers, NPC use prophecies on witchcraft as instruments of their ministry. However, when Pentecostal prophecies result in the defamation of people's character, division of families, destruction of finances and other psychological problems, the fear of witchcraft is not confronted but propagated among the followers of NPCs. Identifying someone as a witch in front of the whole world aids the infliction of fear among the congregants. Therefore, instead of dealing with the problem of witchcraft, the NPCs have initiated another problem of witch-hunting in the form of prophecy. Since prophetic ministry is central to Pentecostalism, not only in Africa, the final section of this paper discusses ways in which prophecy can be done without propagating the fear of witchcraft.

\section{Rethinking Pentecostal prophecies}

The preceding pages have identified that the consequences and challenges of Pentecostal prophecies on witchcraft in their ecclesial, social, and pscyhological dimensions are primarily communal. This concluding section identifies four areas of prophetic activity in light of the impact of prophecy on the community and suggests ways to rethink prophetic praxis in terms of edification, unification, discernment, and affirmation.

\section{Prophecy as edification}

Pentecostal prophets should always consider the way they conduct the activity by being mindful of the content of the prophecy and the way they deliver the

\footnotetext{
${ }^{37}$ Baloyi, "The Evangelical Role of Witchcraft," $56-71$.

${ }^{38}$ Asamoah-Gyadu, "Witchcraft Accusations and Christianity in Africa," 23-27.

${ }^{39}$ Quayesi-Amakye, "This Nonsense Must Stop," 12.

${ }^{40}$ Anderson and Otwang, Tumelo: The Faith of African Pentecostals in South Africa.
} 
message. Prophecy should build up communities and individuals instead of destroying them; it should be done for the edification of the believers and not their destruction. The proper focus of prophecy is 'a truthful speech inspired by the Spirit which imparts instruction, offers some combination of encouragement and consolation, and edifies believers' ${ }^{41}$ Hence, prophetic activity must agree with the apostle Paul that

those who prophesy speak to other people for their upbuilding and encouragement and consolation. Those who speak in a tongue build up themselves, but those who prophesy build up the church ... One who prophesies is greater than one who speaks in tongues, unless someone interprets, so that the church may be built up. (1 Corinthians $14: 3-5)$

We learn from this passage that when prophecy is delivered in the church, it must be for edifying the listener not to ruin their character in the public. Similarly, the Pentecostal prophecies on witchcraft should have the purpose of edifying not only the individual but also the whole congregation and the community at large. In addition, if the prophecy is going to be broadcasted on television or elsewhere in media, the people listening to it should be edified as well.

\section{Prophecy as unification}

The destructive socio-ethical power of Pentecostal activity carried out under the umbrella of prophetic ministry highlights the importance of training prophetic leadership in the mechanisms and goals of socially sensitive Christian work. It was for the goal of building up the believers and the congregation that Paul encouraged the church at Corinth to pursue prophecy. ${ }^{42}$ In fact, the idea of writing the letter to the Corinthians was to address 'disunity, dissensions and factionalism' 43 and prophecy is identified as one of the tools used to achieve this goal. Therefore, 'Paul sees early Christian prophecy as an active and constructive force in the up building of the faith community at Corinth'. ${ }^{44}$ Similarly, Pentecostals have identified the importance of the work of the Spirit in the formation and unity of the community. ${ }^{45}$ The NPCs prophecy must be assessed over against its ability to build up and unite families and individuals in the church and the community, especially if the attention is placed on exposing the work of the devil and demonic powers. Prophecy must be a gift to the community. Conversely, a false gift and the way it is administered will bring adverse effects on the community. Thus, in prophesying to their congregations, the NPC prophets must guard against prophecies that divide. They should pursue prophecies that will change the lives of the people and encourage families to be

\footnotetext{
${ }^{41}$ Ellington, "Be Cautious about Prophets," 174-90.

${ }^{42}$ Ellington, "Be Cautious about Prophets," 5.

${ }^{43}$ Hogeterp, "Prophecy and the Prophetic as aspects of Paul's Theology," 169-96.

${ }^{44}$ Ibid., 192.

${ }^{45} \mathrm{Cf}$. Wenk, Community-Forming Power.
} 
united, so that the communities in which NPCs are located will benefit from the Pentecostal ministry. When such benefits are measurable, the prophetic activity at the root of the churches' activity will bear positive fruit.

\section{Prophecy as discernment}

Prophecy is an important gift especially when used to edify individuals and congregations. However, the same gift can be used dangerously by the so-called prophets, since prophetic activity involves an exposure of spiritual insights that are normally hidden. ${ }^{46}$ Since prophetic work can be abused and misdirected, even if simply ignorant of the implications of public ministry, congregations are called upon to differentiate what is right or wrong. ${ }^{47}$ Hence, Paul says that 'we know in part and we prophesy in part' (1 Corinthians 14:9). If prophecy is imperfect, even when the prophet claims to have heard from the Holy Spirit, the congregation must be sure that indeed the prophet is hearing from God. It is for the reasons of the imperfection of prophecy that the prophet must test such prophetic insight before a prophet can call someone a witch. Even so, it is unnecessary and unethical to declare someone a witch in public, as we can learn from the history of witch trials during the Middle Ages, especially if the prophet does not have evidence for their claims. Therefore, it is also necessary for the leaders in congregation to discern the activity of the accused as well as the manner in which this allegation is presented. ${ }^{48}$ Such discernment must reconsider if a prophecy should be made public, as some prophecies may not stand up to verification and the consequences of public allegations can be more devastating than intended by the churches.

\section{Prophecy as affirmation}

In the final instance, the NPC cases demand that prophetic activity identifies potentially harmful behaviour by affirming the principles of the community of faith. Prophecy should be used to affirm scripture instead of negating what the scriptures are saying in relation to the matter, so that 'knowledge and revelation shared by Christian prophets should not contradict or alter the revelation which we find in Scripture. Prophecy should quicken believers to live according to Scripture in fresh ways'. ${ }^{49}$ In turn, those who receive prophecy should be able to test it in relation to what they have read in scripture and by sound principles of spiritual discernment. ${ }^{50}$ That this principle is not upheld by many of the NPC followers allows the word of the prophet to reign supreme over the words of

\footnotetext{
${ }^{46}$ Hogeterp, "Prophecy and the Prophetic as Aspects of Paul's Theology," 5.

${ }^{47}$ lbid., 7.

${ }^{48}$ Ellington, "Be Cautious about Prophets," 7.

${ }^{49}$ lbid., 11.

${ }^{50}$ lbid., 11
} 
Scripture. Consequently, most of the Pentecostals believe that the Bible should be supplemented with the words of the prophet and that the prophetic word is final. ${ }^{51}$ In the end, NPC prophets face the question if the prophecies they deliver do not compromise their beliefs in the divine inspiration and ultimate authority of the biblical word. Alternatively, if they simply ignore the Scriptures when they give a special prophecy to an individual, the prophetic activity becomes irreconcilable with the biblical image of the prophet and prophetic ministry in the churches.

\section{Conclusion}

At the heart of prophetic activity in South African Pentecostalism stands the relationship between societal problems and witchcraft. Most works on witchcraft have concentrated on the confrontation of witchcraft by Pentecostals through deliverance ministries and other measures. This paper, while it acknowledges the confrontation of Pentecostals with the fear of witchcraft, on one hand, points out the propagation of the same fear by the NPC, on the other. The propagation of the fear of witchcraft is primarily evident in the compromise of human dignity, division of families, destruction of marriages, and other socio-ethical and psychological consequences of public prophecy. Further studies will likely discover additional ways in which the Pentecostal prophecies on witchcraft create rather than dispel fear and anxiety. In response, the Pentecostal community must discern the strategies used by NPC prophets and develop sufficient criteria of the discernment of prophecy that includes questions on how the prophets benefit from both the diagnosis of witchcraft and the relationship between the fear of witchcraft and the commercialization of the gospel. The goal of the prophetic ministry is not exposure of witchcraft but deliverance, and not at the cost of destroying individuals, families, and churches but for the purpose of healing for the entire community.

${ }^{51}$ Deke, "The Politics of Prophets," 11-24. 


\section{Bibliography}

Anderson, A., and S. Otwang. Tumelo: The Faith of African Pentecostals in South Africa. Pretoria: University of South Africa, 1993.

Anderson, A. "New African Initiated Pentecostalism and Charismatics in South Africa." Journal of Religion in Africa 35, no. 1 (2005): 66-92.

Adinkrah, M. "Child Witch Hunts in Contemporary Ghana." Child Abuse \& Neglect 35, no. 9 (2011): 741-752.

Asamoah-Gyadu, J. K. "Witchcraft Accusations and Christianity in Africa." International Bulletin of Missionary Research 39, no. 1 (2015): 23-27.

Baloyi, M. E. "A Pastoral Examination of the Christian Church's Response to Fears of and Reactions to Witchcraft Amongst African People in the Limpopo Province of South Africa." HTS Teologiese Studies/Theological Studies 70, no. 2 (2014). doi:10.4102/hts. v70i2.1317.

Baloyi, E. M. "The Evangelical Role of Witchcraft in Some Pentecostal Movements - An African Pastoral Concern." Missionalia 46, no. 3 (2018): 56-71.

Banda, C., and G. Masengwe. "Overcoming Fear? A Search for an Empowering Theological Response to the Fear of Witchcraft among Urban Zimbabwean Christians." Verbum et Ecclesia 39, no. 1 (2018): 1-10.

Banda, C. "A Soteriological Response to the Congolese Pastors' Engagement with Children Accused of Being Witches." OKH Journal: Anthropological Ethnography and Analysis Through the Eyes of Christian Faith 4, no. 1 (2020). doi:10.18251/okh.v4i1.71.

Chimuka, T. A. "Afro-Pentecostalism and Contested Holiness in Southern Africa." Studia Historiae Ecclesiasticae 42, no. 1 (2016): 124-141. doi:10.17159/2412-4265/2016/307. Deke,

A. "The Politics of Prophets and Profits in African Christianity." Politics 12, no. 1 (2015): 11-24.

Dube, B. "'Go and Prophesy in Your Own Land': Foreign Prophets and Popularism in South Africa. Evoking the Need of Jonathanic Theology for Peaceful Resolution of Difference." Religions 11, no. 1 (2020): 42.

Ellington, D. W. "Be Cautious About Prophets but Zealous to Prophesy: 1 Corinthians 14 and Today's Questions About Prophecy.” In Prophecy Today: Reflections From a Southern African Context, edited by Hermen Kroesbergen, 174-190. Johannesburg: Christian Literature Fund Publishers, 2016.

Hogeterp, A. "Prophecy and the Prophetic as Aspects of Paul's Theology." Stellenbosch Theological Journal 4, no. 2 (2018): 169-196.

Kekana, C. "Tswara Moloi-Pastor Mboro is on a Mission to Stop Witchcraft." Sunday Times, June 15 , 2019. https://www.timeslive.co.za/tshisa-live/tshisa-live/2019-06-05tswaramoloi-pastor-mboro-is-on-a-mission-to-stop-witchcraft/.

Kgatle, M. S. "Reimagining the Practice of Pentecostal Prophecy in Southern Africa: A Critical Engagement." HTS Teologiese Studies/Theological Studies 75, no. 4 (2019): 8.

Kgatle, M. S. The Fourth Pentecostal Wave in South Africa: A Critical Engagement. London: Routledge, 2019.

Macnamara, J. R. "Media Content Analysis: Its Uses, Benefits and Best Practice Methodology." Asia Pacific Public Relations Journal 6, no. 1 (2005): 1-34.

Mashau, D. T. "Ministering Effectively in the Context of Pentecostalism in Africa: A Reformed Missional Reflection." In die Skriflig 47, no. 1 (2013): 10-17. 
Mothombeni, A. "Bushiri Sued Millions over Witchcraft Prophecy." Sunday World, April 15, 2018. https://www.sowetanlive.co.za/sundayworld/news/2018-04-15-bushiri-sued-millionsover-witchcraft-prophecy.

Onyinah, O. "Deliverance as a Way of Confronting Witchcraft in Modern Africa: Ghana as a Case History." Asian Journal of Pentecostal Studies 5, no. 1 (2002): 107-134.

Pastor Alph Lukau. "5 Cows for Witchcraft Initiation - Accurate Prophecy with Alph Lukau." https://www.youtube.com/watch?v=NdPNeES5BiQ.

Prophet Shepherd Bushiri. "The Prophetic Gymnastics: Exposing Witchcraft Spirit." https:// www.youtube.com/watch?v=olXw2F5BjKo.

Quayesi-Amakye, J. "This Nonsense Must Stop! Pentecostal Negotiation of Evil." Australasian Pentecostal Studies 17 (2015). https://aps-journal.com/index.php/APS/ article/view/9480/9484.

Ramantswana, H. "Prophets Praying for, or Preying on People's Faith: A Reflection on Prophetic Ministry in the South African Context." In die Skriflig/ln Luce Verbi 53, no. 4 (2019): 8.

Sangala, T. "Shepherd Bushiri hands himself to South Africa police." The Times Malawi, May 7, 2018. https://times.mw/shepherd-bushiri-hands-himself-to-sa-police/.

Sanou, B. "Witchcraft Accusations: Destroying Family, Community, and Church." Journal of Adventist Mission Studies 13, no. 1 (2017): 33-44.

Tedam, P. "Witchcraft Branding and the Abuse of African Children in the UK: Causes, Effects and Professional Intervention." Early Child Development and Care 184, no. 9-10 (2014): 1403-1414.

Tsekpoe, C. "Contemporary Prophetic and Deliverance Ministry Challenges in Africa." Transformation 36, no. 4 (2019): 280-291.

Tweneboah, S. "Pentecostalism, Witchdemonic Accusations, and Symbolic Violence in Ghana: Some Human Rights Concerns." Pneuma: The Journal of the Society for Pentecostal Studies 37, no. 3 (2015): 375-393.

Wenk, M. Community-Forming Power: The Socio-Ethical Role of the Spirit in Luke-Acts. London: T\&T Clark, 2000. 